\title{
Utilization of Parupuk Plants (Phragmites Karka) To Reduce Mercury Levels In Waters Former Of Diamond And Golden Mining
}

\author{
Lailan Ni mah $^{1, *}$, Muhammad Adzhari Anshari ${ }^{1}$, Hari Apriyan Saputra ${ }^{1}$, Adi Rahmadi $^{2}$, and \\ Ulfa Fitriati $^{3}$ \\ ${ }^{1}$ Chemical Engineering Department, Engineering Faculty, Lambung Mangkurat University, Banjarbaru \\ 70714, Indonesia \\ ${ }^{2}$ Forest Science Departement, Forestry Faculty, Lambung Mangkurat University, Banjarbaru 70714, \\ Indonesia \\ ${ }^{3}$ Civil Engineering Department, Engineering Faculty, Lambung Mangkurat University, Banjarbaru \\ 70714, Indonesia
}

\begin{abstract}
The waters in Cempaka Sub-district have been contaminated by heavy metals that exceed the quality of waste water standard. The process that can be used to reduce waste pollution is by phytoremediation method. Phytoremediation is a method of waste degradation using plant capability. One of the plants is the parupuk plant (phragmites karka). Parupuk plant (Phragmites karka) has a big ability to degradation the waste. Parupuk plant was included in poaceae family. The purpose of this study is to analyze the influence of mass variations and the duration of immersion of parupuk plants in absorbing heavy metals mercury. In this study begins with static phytoremediation was performed by plant mass variation of $0.5 \mathrm{~kg}, 1 \mathrm{~kg}$ and $1.5 \mathrm{~kg}$. The Soaking period of 8 hours, 80 hours, 152 hours and 224 hours. From the result of research known, the effective condition for the parapuk plant to absorbs the heavy metals mercury is at the 8th hour of phytoremediation and $1.5 \mathrm{~kg}$ parupuk plant can absorb the heavy metals mercury by $90,74 \%$.
\end{abstract}

\section{Introduction}

Mercury is a compound as well as other metals which are toxic and are widespread. In daily life, the use of mercury has grown very broad, and one of them in the traditional gold mining process[1]. It was recorded several events of Mercury poisoning that occurred in the World such as the case in Minamata that killed 111 people, in Iraq, 35 people died 321 injured, and Guatemala 20 people died 45 injuries caused mercury poisoning[2]. In Indonesia, there has been a case of mercury poisoning that is enough to be the concern of Buyat Bay case that occurred due to the mercury content in fish consumed by the community[3].

Cempaka sub-district is one of the District in the City Government Banjarbaru. One of the activities carried out by the community there is the mining of various precious metals,

* Corresponding author: lailan.nimah@gmail.com 
including gold and diamond. For diamond mining is usually passed on, it is they do for a living. In the mining activities are obtained materials [4,5] such as gold which follow to separate the gold by using mercury, causing the waters around the area is polluted by heavy metals mercury because of the flow of water directly into the river. Based on research[6], in the District Cempaka polluted waters, heavy metals that exceed the threshold of waste water quality standard is $0.02 \mathrm{mg} / \mathrm{l}$ according to PP 82 of 2001 on the waste water quality standards for mercury content.

One of the alternatives that could be used to reduce mercury pollution is the manufacture of a wide variety of biomaterials adsorbent. This way is too complicated and requires a considerable cost, therefore, needed a cheap alternative more efficient method is the method of phytoremediation. The definition of phytoremediation method is a method that use of plants to remove, remove, stabilize, or destroy the contaminants be it organic or inorganic compounds. Phytoremediation is the use of the ability of hyperaccumulator plants, the ability of plant hyperaccumulator is the ability of plants to reduce the level of heavy metal pollution in polluted waters. All plant species have hyperaccumulation in small amounts[7]. Plants often used Anthurium Red/Yellow, Alamanda Yellow/Purple, Fragrant Root, Bamboo Water, Cana President Red/Yellow/White, Dahlia, Purun Tikus, and Kiambang. Based on research[8] one member of the plant family that has the ability hiperaccumulator is a member of the Poaceae family[9]. One of the plants that belong to the family of Poaceae is the plant of parupuk.

Parupuk plants are plants that usually live in swamp areas. Therefore, the distribution of this plant is very much in South Kalimantan area famous for its area. Parupuk plant is very potential in reducing mercury metal waste in the waters because the spread is very comprehensive and easy to obtain. So researchers are interested to determine the influence of variation of many plants and the long immersion of parupuk plants (Phragmites karka) in absorbing heavy metals mercury $(\mathrm{Hg})$ in diamond mining waste in Cempaka Districts. The expectation from this research is that this plant can be an effective medium in the phytoremediation of heavy metals, especially mercury.

\subsection{Mercury}

Mercury or Hydrargyrum is a chemical element in the periodic table with the symbol $\mathrm{Hg}$, atomic number 80 and molecular weight of 200.59. The mercury in nature is found in three forms: $\mathrm{Hg}, \mathrm{Hg}_{2}{ }^{2+}, \mathrm{Hg}^{2+}$. Coordination of the nervous system, and intelligence, as well as diminished hearing and sight. Dose levels that can cause death are if the $\mathrm{Hg}$ levels that enter the body as much as 0.2 to 1.0 grams. When people breathe air containing mercury vapor $>$ $100 \mu \mathrm{g} / \mathrm{m}^{3}$ daily for 5 - 8 hours it will cause dysfunction in various organs of the body. Mercury began to be used one of them in the field of cosmetics and gold mining industry[10].

\subsection{Gold and Diamond Mines in Pumpung Village, Cempaka Subdistrict, South Kalimantan}

Gold and Diamonds are usually found in river deposits. At present, there are at least $23,514,000 \mathrm{~m}^{3}$ of land cover that is used as diamond mining location in Cempaka District, one of them is in Pumpung Village Tiung River. Excavation of the hole has been flows of water directly streamed into the river, of course, this causes pollution in the river. Here is the appearance of traditional diamond mining in Pumpung Village, Tiung River, Cempaka Subdistrict, Kab. Banjar, South Kalimantan can be seen in Figure 1. 


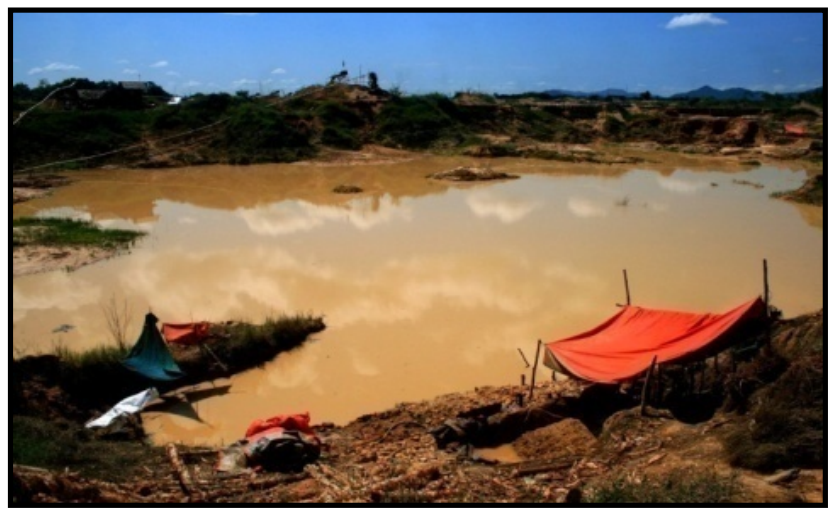

Fig. 1. Traditional Diamond Mining in Pumpung Village, Tiung River, Cempaka Subdistrict, Banjar District, South Kalimantan

\subsection{Phytoremediation}

Phytoremediation is a system whereby certain crops that work with micro-organisms in the media (soil, corals, and water) can convert contaminants (pollutants) into less or harmful and even become economically useful materials. Hyperaculum is a plant that can absorb heavy metals about $1 \%$ of its dry weight[11]. All plants can absorb the metals but in varying amounts. Some plants from many families proved to have the nature of hypertolerance, which can accumulate metals with a high concentration in the root and crown tissue, so it is hyperaccumulator. The hyperaccumulator means to accumulation certain metallic elements with a high concentration in the canopy and can be used for phyto-extraction. In the process of this phyto-extraction heavy metals are absorbed by plant roots and translocated into the canopy to be reprocessed or disposed of when the crop is harvested[12].

The mechanism of absorption and accumulation of heavy metals by plants can be divided into three continuous processes[13], as follows: 1.) Absorptions by roots. For plants to absorb, the metal must be brought into the solution around the roots (rhizosphere) in some way depending on the plant species. Water-soluble compounds are usually taken by roots with water, while hydrophobic compounds are absorbed by the root surface. 2.) Translocate metal from roots to other plant parts. After the metal penetrates the root endodermis, the compounds follow the flow of transpiration to the top of the plant through the carrier network (xylem and phloem) to other plant parts. 3.) To localize the metals in cells and tissues. It aims to keep the metal from inhibiting plant metabolism. To prevent metal poisoning of cells, plants have detoxification mechanisms, for example by hoarding metals in particular organs such as roots.

Characteristics of hyperaccumulator plants are: (i) Resistant to metal elements in high concentrations in root and crown tissues; (ii) High absorption rate of soil elements compared to other plants; (iii) Can translocate and accumulate metallic parts from root to the canopy at a high rapid. This translocation is a component that must be a consideration in the determination of hyperaccumulator plants[14].

Some plant species are known to accumulate mercury in amounts higher than other types. For example, Paspalum Conjugatum is known to accumulate $47 \mathrm{Hg} / \mathrm{kg}$ dry weight, Cyperus Monocephala $13.05 \mathrm{Hg} / \mathrm{kg}$, Ipomea Batatas 18.57-22.57 mg Hg/kg, Zingiber sp $49.33 \mathrm{mg}$ $\mathrm{Hg} / \mathrm{kg}$, Caladium $9.12 \mathrm{mg} \mathrm{Hg} / \mathrm{kg}$, Digitaria Radicosa $50.93 \mathrm{mg} \mathrm{Hg} / \mathrm{kg}$, Commelia Nudi 30.37 $\mathrm{mg} \mathrm{Hg} / \mathrm{kg}$ and Lindernia Crustacea were able to accumulate up to $89.13 \mathrm{mg} \mathrm{Hg} / \mathrm{kg}$. The potential for adaptability and absorption of mercury from some plant species is significant[15]. 
Mechanisms of tolerance in plants are contained in a solution of metal tied with phytochelatin, i.e., small peptides rich in cysteine amino acids containing sulfur. A sulfur atom in cysteine is for the metal binding, but suspected nitrogen or oxygen atoms contribute anyway. Phytochelatin is producing by many species, but so far it is known that phytocelatin is found only when there are metals in poisonous amounts. The formation of phytochelatin is the response of plants to adapt to the hazardous environment[16].

\subsection{Plants Potentially as Hiperaccumulator}

Many types of vascular plants are found to have the ability to accumulate heavy metals. More than 400 plant species have been found to have hyperaccumulator ability including family members of Asteraceae, Brassicaceae, Caryophyllaceae, Cyperaceae, Cunouniaceae, Fabaceae, Flacourtiaceae, Lamiaceae, Poaceae, Violaceae, and Euphorbiaceae. The family most often encountered as a hyperaccumulator Brassicaceae, species of this family can accumulate more than one type of metal. One example is Brassica Juncea able to accumulate $\mathrm{Se}, \mathrm{As}, \mathrm{Cd}, \mathrm{Cu}, \mathrm{Hg}$, and $\mathrm{Zn}$. Thlaspi caerulescens is a $\mathrm{Cd}$ accumulator while Alyssum sp is an accumulator of $\mathrm{Ni}$. Another example, Pistiastratiotes can accumulate $\mathrm{Ag}, \mathrm{Cd}, \mathrm{Cr}, \mathrm{Cu}, \mathrm{Hg}$, $\mathrm{Ni}, \mathrm{Pb}$, and $\mathrm{Zn}$ with concentrations of up to $5 \mathrm{mM}$ per $\mathrm{kg}$ of biomass. Plants of Pistia Stratiotes accumulate metals in root tissues.

Some types of ferns like Pteris vittata can accumulate Other Pteris types such as Pteris Cretica, Pteris Longifolia, and Pteris Umbrosa are also able to accumulation Azolla Caroliniana (Azollaceae) water spikes can be used to clean $\mathrm{Hg}$, and $\mathrm{Cr}$ in water and accumulates in tissues so they can be uses as water purifiers[17].

\subsection{Parupuk plants (Phragmites karka)}

Phragmites karka is the Latin name of the parupuk plant. This plant is a swamp plant has a plant height 4-6 m and stems rigid, segmented, hollow (like bamboo). This plant belongs to the family of Poaceae. One member of the plant family that has hyperaccumulator ability is a member of the family poaceae[17]. Here is the appearance of the parupuk plant[8] can be seen in Figure 2.

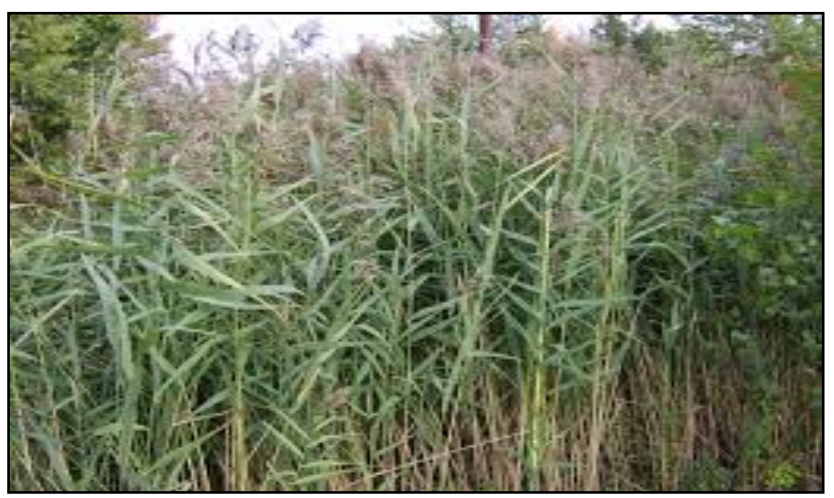

Fig. 2. Parupuk Plants (Phragmites karka)

\section{Materials and Methods}

Former diamond mine waste is taken from the People's Diamond and Gold Mining in the village Pumpung, Tiung River, District Cempaka, Banjar District, South Kalimantan. Parupuk plants (Phragmites karka) taken from Pemurus Dalam, Banjarmasin City. 
The tools used in this experiment include three pieces of storage containers $50 \mathrm{~cm}$ in diameter and $30 \mathrm{~cm}$ high, 12 sample bottles, $\mathrm{pH}$ meters, scales, AAS, 12 Erlenmeyers

In this study there are two variables used, that is :

1. The independent variables, namely variation of the mass of the parupuk ( $\mathrm{S} 1=0.5 \mathrm{~kg}$; $\mathrm{S} 2$ $=1 \mathrm{~kg}$; and $\mathrm{S} 3=1.5 \mathrm{~kg}$ ) and the duration of phytoremediation immersion, for more details can be seen in Table 1 below:

Table 1. The Independent Variables

\begin{tabular}{|c|c|c|c|c|c|}
\hline \multicolumn{2}{|c|}{$\begin{array}{c}\text { The Independent } \\
\text { Variable }\end{array}$} & \multicolumn{3}{c|}{ Length of Phytoremediation (Hours) } \\
\cline { 3 - 6 } & 8 & 80 & 152 & 224 \\
\hline \multirow{2}{*}{$\begin{array}{c}\text { Mass Plant } \\
(\mathrm{kg})\end{array}$} & 0.5 & $\mathrm{~S} 1$ & $\mathrm{~S} 1$ & $\mathrm{~S} 1$ & $\mathrm{~S} 1$ \\
\cline { 2 - 6 } & 1 & $\mathrm{~S} 2$ & $\mathrm{~S} 2$ & $\mathrm{~S} 2$ & $\mathrm{~S} 2$ \\
\cline { 2 - 6 } & 1.5 & $\mathrm{~S} 3$ & $\mathrm{~S} 3$ & $\mathrm{~S} 3$ & $\mathrm{~S} 3$ \\
\hline
\end{tabular}

2. The dependent variable, among other parupuk plants, methods of phytoremediation static, waste mined diamonds, and gold, the volume of waste, container dimensions of phytoremediation.

\subsection{Acclimation of Parupuk Plants (Phragmites karka)}

Plants are selected and weighed approximately $0.5 \mathrm{~kg} ; 1 \mathrm{~kg}$ and $1.5 \mathrm{~kg}$ according to the size of \pm 1 meter. Parupuk plants (Phragmites karka) were acclimated in a tub of acclimation for one week in three $50 \mathrm{~cm}$ diameter and 30 meter high basins before being used in the study. Acclimation process by taking part of the land from the original environment where the plant grows.

\subsection{Phytoremediation Process}

The sample is taken from the specified gold mining tailing water, after which the sampling device is a bucket and the sample storage of jirigen is prepared. Then the sampling is done by inserting the bucket into the tailings water of the sample source and transferred into the storage jug.

Fibers are arranged in a mold with some variation of the his study uses static phytoremediation method (water in phytoremediation in a state of silence or not flowing)[18]. A sample of 30 liters was inserted into the basin where the acclimated parapuk was then sampled. The total mercury $(\mathrm{Hg})$ concentration was measured by Atomic Absorption Spectrophotometer (AAS) with a wavelength of $253.6 \mathrm{~nm}$ at the period to 8; 80; 152 and 224 phytoremediation, to determine the level of mercury decrease. During phytoremediation treatment, $\mathrm{pH}$ measurements were performed with $\mathrm{pH}$-meters and observed parameters of plant growth change, discoloration of leaves and roots[19].

\section{Results And Discussion}

Stages in phytoremediation are divided into three processes; the first process is the absorption by the roots by forming a substance called chelate called fotosiderofor which will bind the metal and bring it into the root cell via active transport. The second process is the translocation of metals from the roots to other parts of the plant through the transport network of xylem and phloem and the third process of the presence of metals in certain cell parts to keep from inhibiting plant metabolism[20].

For the analysis of mercury levels in this study was done by the AAS method. Results of analysis after phytoremediation by using parupuk plant can be seen in Table 2, below: 
Table 2. Results of Mercury Measurement after Phytoremediation

\begin{tabular}{|c|c|c|c|c|c|}
\hline \multirow{2}{*}{$\begin{array}{c}\text { Hg Parameter } \\
(\mathrm{mg} / \mathrm{L})\end{array}$} & \multicolumn{4}{|c|}{ Length of Phytoremediation (Hours) } \\
\cline { 2 - 6 } & 8 & 80 & 152 & 224 \\
\hline \multirow{2}{*}{$\begin{array}{c}\text { Plant } \\
\text { Mass } \\
(\mathrm{kg})\end{array}$} & 0.5 & 0.0233 & 0.0162 & 0.0085 & 0.0021 \\
\cline { 2 - 6 } & 1.5 & 0.0099 & 0.0026 & 0.0051 & 0.0017 \\
\hline
\end{tabular}

Based on Table 2, phytoremediation effectiveness can be made with parupuk plants. Based on[21], effectiveness can be analyzed by calculating the effectiveness of the decrease (E) ie the weight of the initial heavy metal (Yi) minus the final heavy metal content (Yf).

$$
(\mathrm{Ef} \%)=\frac{Y i-Y f}{Y i} \times 100 \%
$$

The results of the calculation of effectiveness of $\mathrm{Hg}$ phytoremediation using parupuk plants can be seen in Table 3 below:

Table 3. The effectiveness of $\mathrm{Hg}$ Phytoremediation Using the Parupuk Plant

\begin{tabular}{|c|c|l|l|l|}
\hline \multirow{2}{*}{$\begin{array}{c}\text { Plant } \\
\text { Mass } \\
(\mathrm{kg})\end{array}$} & \multicolumn{4}{|c|}{ Length of Phytoremediation } \\
\cline { 2 - 5 } & 8 Hours & 80 Hours & 152 Hours & 224 Hours \\
\hline 0.5 & $41.66 \%$ & $30.49 \%$ & $47.90 \%$ & $76.17 \%$ \\
\hline 1 & $75.27 \%$ & $73.59 \%$ & $-96.5 \%$ & $66.51 \%$ \\
\hline 1.5 & $90.74 \%$ & $47.90 \%$ & $12.91 \%$ & $82.07 \%$ \\
\hline
\end{tabular}

According to Table 3, the most effective phytoremediation conditions were on a $1.5 \mathrm{~kg}$ plant mass with an 8-hour phytoremediation duration. This is in accordance with the theory that more plants are more effective in absorption[22] and the condition of the plant is still in fresh condition so that the ability of hyperakumulator is still optimal. A graph comparison between the phytoremediation time and the mass of the parapuk plant will be made. Can be seen in Figure 3 below:

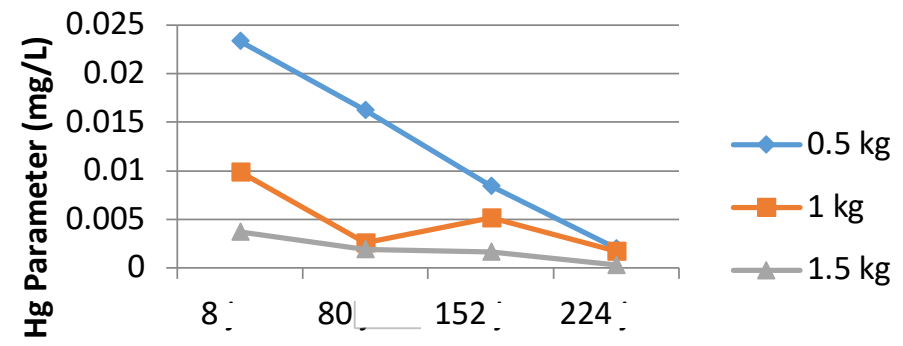

\section{Length of Phytoremediation (Hours)}

Fig. 3. Graph of the Comparison Between Mercury Decrease and Phytoremediation Duration at Each Mass of the Parapuk Plant

Based on Figure 3, the phytoremediation time at 8th hour, for samples with $0.5 \mathrm{~kg}$ of $\mathrm{Hg}$ plant mass is $0.0233 \mathrm{mg} / \mathrm{l}$, for samples with $1 \mathrm{~kg}$ plant mass of $0.009892 \mathrm{mg} / \mathrm{l}$ while for samples with mass $1.5 \mathrm{~kg}$ plant is $0.003701 \mathrm{mg} / \mathrm{l}$ for plants with a mass of $0.5 \mathrm{~kg}$ seen slope of the chart down drastically. This is due to the fact that at 8 hours phytoremediation of the plant with the lowest mass is only able to absorb less than the plant with its higher mass. This is in accordance with research conducted by[22] which proves that the mass of the plants 
affects the absorption of heavy metals, the greater the number or mass of plants the greater the absorption of such heavy metals.

The duration of phytoremediation at the 80th hour for samples with $0.5 \mathrm{~kg}$ of plant mass is $0.016219 \mathrm{mg} / \mathrm{l}$ very significant decrease for this many factors that influence other than the plant condition the degree of acidity also affects due to the aqueous metal will be stable at low pH[2]. Samples with a plant mass of $1 \mathrm{~kg} \mathrm{Hg}$ level of $0.002612 \mathrm{mg} / \mathrm{l}$, while the sample with a plant mass of $1.5 \mathrm{~kg}$ is $0.001928 \mathrm{mg} / \mathrm{l}$.

Based on the graph, it can be seen that the plant of parupuk (phragmites karka) until the 9th day is still on the stationary phase and can be seen also that the most effective variation in phytoremediation using the parupuk plant is $1.5 \mathrm{~kg}$ mass with 8 hours of soaking time. The following comparison of research results with waste[23,24] water quality standards according to Regulation of Indonesian republican government regulation number 82 of 2001 and Permenkes RI No.416/menkes/Per/IX/90 on water quality management and water pollution control as a measure of limits or levels of pollutants for standard the quality of waste water can be seen in Table 4, as follows:

Table 4. Comparison of Research Results with Wastewater Quality Standards

\begin{tabular}{|c|l|l|c|c|c|c|}
\hline \multirow{3}{*}{ Parameter } & \multicolumn{2}{|c|}{$\begin{array}{c}\text { After } \\
\text { Phytoremediation }\end{array}$} & \multicolumn{2}{c|}{ PP No.82 Year 2001 } & \multicolumn{2}{c|}{$\begin{array}{c}\text { Permenkes RI } \\
\text { No.416/menkes/ Per/IX/90 }\end{array}$} \\
\cline { 2 - 7 } & \multicolumn{2}{|c|}{ Massa } & Standar & suitability & Standar & suitability \\
\hline \multirow{3}{*}{$\mathrm{Hg}$} & $0,5 \mathrm{~kg}$ & 0.00213 & 0.02 & suitable & 0.02 & suitable \\
\cline { 2 - 7 } & $1 \mathrm{~kg}$ & 0.0017 & 0.02 & suitable & 0.02 & suitable \\
\cline { 2 - 7 } & $1,5 \mathrm{~kg}$ & 0.00013 & 0.02 & suitable & 0.02 & suitable \\
\hline
\end{tabular}

\subsection{Plant Characteristics Changes}

The change of plant characteristic in this study is only observed by direct observation of both the condition, shape, and color of plants in which the change in the characteristics of this plant is influenced by several factors, the most important factor is the nutrients of the plant nutrient deficiencies in plants can make changes in shape and color plant. Its shape will shrink, and the color will turn yellow is a symptom of the plant is dead or wilted. For the condition of plants at hours 80 and 152 can be seen in Figure 4.

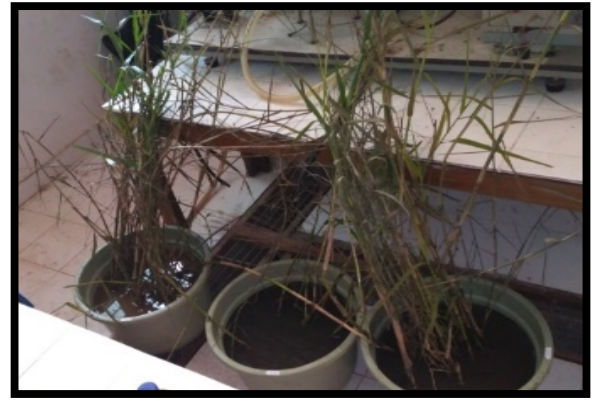

a)

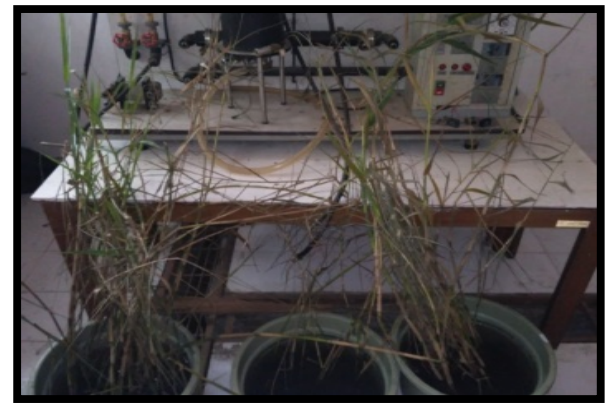

b)

Fig. 4. a) Plant Condition at 80 Hours of Phytoremediation, b) Plant Condition at 152 Hours of Phytoremediation

Based on Figure 4, seen the condition of the plants on the sampling at the 80th hour of the leaves form is still green although there are some stems of plants that have begun to wilt while the plants on the sampling hour of his 152 stems have begun yellowing is due to the 
intake of plant nutrients have started to run out thus causing the condition of the plant to wither or die other than it is also due to its heavy metal accumulation factor.

For plant conditions on sampling $224^{\text {th }}$ Hour can be seen in Figure 5, as follows:

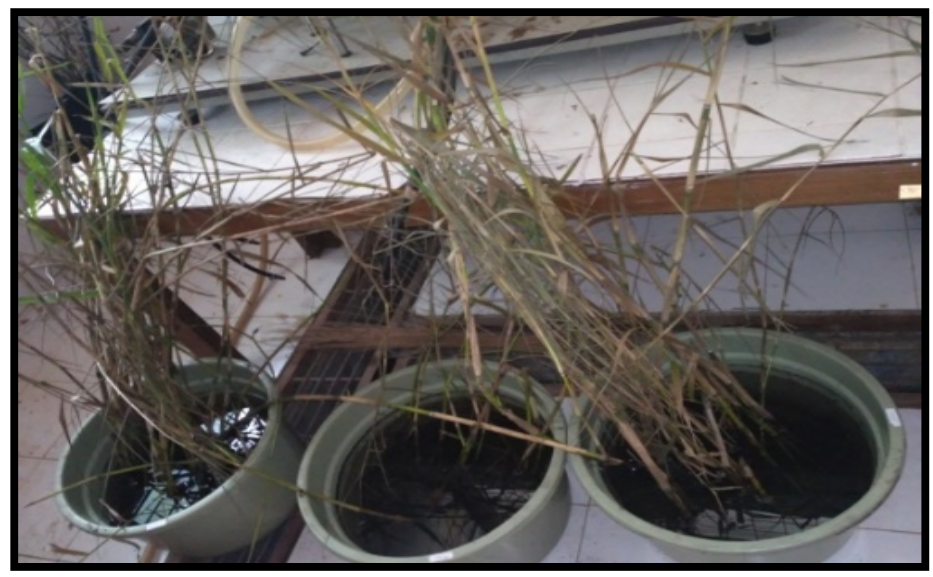

Fig. 5. Plant Condition at Hour $224^{\text {th }}$ of Phytoremediation

Based on Figure 5, it can be seen that the condition of the plants has yellowing stems begin to shrink indicating the plant has entered its phase of death. But from the observation, there are on certain parts of this plant overgrown by new shoots can be seen in Figure 6, as follows:
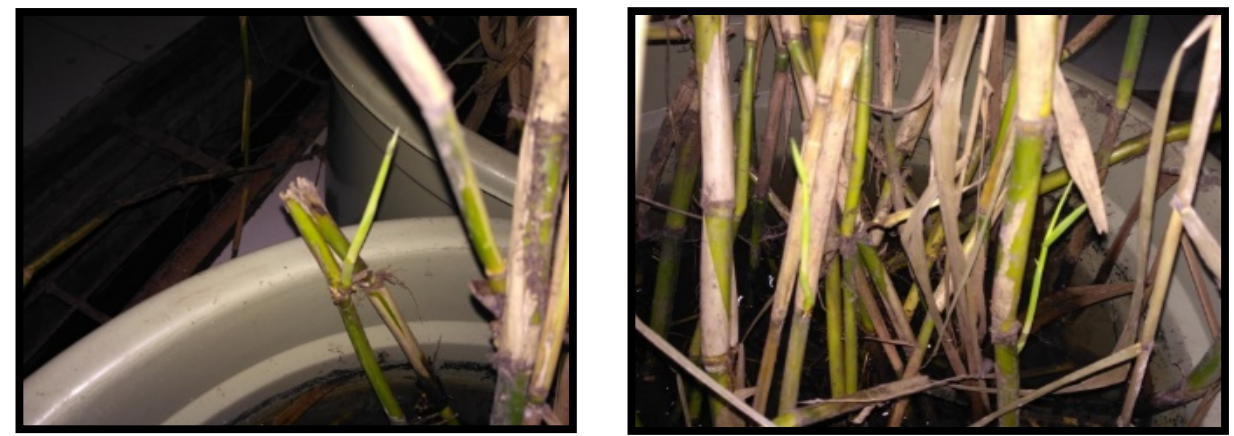

Fig. 6. The growth of New Shoots On Phytoremediation Plants (Parupuk)

Based on Figure 6, shows the growth of new shoots. This proves that the acclimation stage in this study can be said successful and the plant grows stable and can survive in the presence of heavy metals contained in the liquid.

\section{Conclusion}

Based on the results of the research, it was concluded as follows:

1. The optimum condition of phytoremediation is at the 8 th hour with plant mass $1.5 \mathrm{~kg}$ with the effectiveness of $90.74 \%$.

2. The more plant mass for phytoremediation, the greater the absorption capacity of the pollutant, while the longer the immersion, the absorption of the plant against the pollutant metal decreases. 


\section{References}

1. Akuba, Nasrudin., Status Lingkungan Hidup Daerah Provinsi Gorontalo 2007, Provinsi Gorontalo, Badan Lingkungan Hidup, Riset dan Teknologi Informasi. (2008)

2. Palar, Pencemaran dan Toksikologi Logam Berat. Rinneka Cipta, Jakarta. (1994)

3. Lestarisa, T., Faktor-faktor yang berhubungan dengan Keracunan pada merkuri (Hg) pada Penambangan Emas Tanpa Izin di Kecamatan Kurun, Kabupaten Gunung Mas, Kalimantan Tengah, Program Pascasarjana, UNDIP, Semarang. (2010)

4. Ni 'mah, L., Akbari, M.R., Khan, F.A., Ma'ruf, M.A., Manufacture Of Fiber Composite Materials Musa Acuminate L. Prepared By The Randomized Position With Polymer Matrix Resin, Matec Web of Conference 154, 01006 (2018), DOI: https://doi.org/10.1051/matecconf/201815401006, https://www.matecconferences.org/articles/matecconf/pdf/2018/13/matecconf_icet4sd2018_01006.pdf (2018)

5. Ach. Kusairi, S., Ni mah, L., Utilization Fibers and Palm Kernel Shells and Tapioca Adhesive as Matrix in the Manufacture of Composite Boards as an Alternative Raw Material in Furniture Industry, International Journal of ChemTech Research, CODEN (USA): IJCRGG, ISSN: 0974-4290, Vol. 8.,No.4, p. 1645-1655. (2015)

6. Maulidah, Priatmadi B.J.,Asmawi, S., Sofarini, D., Kajian Indeks Pencemaran Air Pada Areal Pertambangan Rakyat Intan Dan Emas Di Kecamatan Cempaka Kota Banjarbaru. Jurnal EnviroScienteae, Vol. 11 No.2, ISSN: 1978-8096, Online ISSN: 2302-3708. (2015)

7. Chaney, RL., Brown, SL., YM Li, Angle, JS., Homer, F., Green, C., Potential use of metal hyperaccumulators, Mining Environ Management 3(3):9-11. (1995)

8. Widyati, Potensi Tumbuhan Bawah Sebagai Akumulator Logam Berat Untuk Membantu Rehabilitasi Lahan Bekas Tambang, Jurnal Mitra Hutan Tanaman, Vol.6 No. 2, ISSN: 1978-0370, p. 46 - 56. (2011)

9. Yoandestina, Parupuk Sedang Diteliti. http://balittra.litbang.pertanian.go.id. Akses at October $9^{\text {th }}$ 2016. (2014)

10. Alfian, Z., Merkuri: Antara Manfaat Dan Efek Penggunaannya Bagi Kesehatan Manusia Dan Lingkungan, Pidato Pengukuhan Jabatan Guru Besar Tetap, USU, Medan. (2006)

11. Fahruddin, Bioteknopologi Lingkungan, Penerbit Alfabeta, Bandung. (2010)

12. Hidayati, N., Fitoremediasi Dan Potensi Tumbuhan Hiperakumulator, Pusat Penelitian Biologi, Lembaga Ilmu Pengetahuan Indonesia, Vol. 12 No. 1, ISSN:0854-8587, p. 3540. (2005)

13. Hardiani, H., Potensi Tanaman Dalam Mengakumulasi Logam $\mathrm{Cu}$ Pada Media Tanah Terkontaminasi Limbah Padat Industri Kertas. Jurnal BS Vol. 44, No. 1, 27-40. (2009)

14. Agunbiade F, B.I., Olu-owolabi, Kayode O, Adebowale, Phytoremediation Potential of Eichornia Crassipes in Metal Contaminated Water, Bioresource Technology, 100, 45214526. (2009)

15. Juhaeti, T., Hidayati N., Syarif, F., Pemanfaatan Salvinia Molesta D.S. Mitchell, Akumulator Merkuri Di Sawah Tercemar limbah Penambangan Emas. Jurnal Teknik Lingkungan Vol. 10, No. 3, p. 249-256. (2009)

16. Safitri, R., Phytoremediation Greywater Dengan Tanaman Kayu Apu (Pistia stratiotes) dan Tanaman Kiambang (Salvinia molesta) Serta Pemanfaatannya Untuk Tanaman Selada (Lactua sativa) Secara Hidroponik, Program Studi Ilmu Tanah, Fakultas Pertanian, IPB, Bogor. (2009) 
17. Widyati, Potensi Tumbuhan Bawah Sebagai Akumulator Logam Berat Untuk Membantu Rehabilitasi Lahan Bekas Tambang, Mitra Hutan Tanaman. 6 (2): 46 - 56. (2011)

18. Permatasari, A.A., Fitoremediasi Logam Berat Cd Menggunakan Ki Ambang (Salvinia Molesta) Pada Media Modifikasi Air Lumpur Sidoarjo, Skripsi, Biologi FMIPA - ITS. (2009)

19. Chaney, R.L., Brown, S.L., Angle, J.S., Improving Metal Hyperaccumulators Wild Plants to Develop Commercial Phytoextraction System: Approaches and Progress. in: Proc Symp Phytoremediation, Inc Conf Biochemistry of Trace Elements. 23-26 Juni 1998. Berkly, CA. (1998)

20. Syahputra R, Fitoremediasi Logam $\mathrm{Cu}$ dan $\mathrm{Zn}$ dengan Tanaman Enceng Gondok. Jurnal LOGIKA, ISSN : 1410 - 2315, Vol 2, No 2, p. 57 - 67. (2005)

21. Larasati, A.I., Susanawati, L. D., Suharto, B., Efektivitas Adsorpsi Logam Berat pada Air Lindi menggunakan Media Karbon Aktif, Zeolit, dan Silika Gel di TPA Tlekung Batu, Jurnal Sumberdaya Alam dan Lingkungan, Vol. 2, No. 1, p. 44-48. (2015)

22. Belami, Pemanfaatan Purun Tikus (Eleochalis Dulcis) Untuk Menurunkan Kadar Merkuri (Hg) Pada Air Bekas Penambangan Emas Rakyat, Prodi Biologi, Fakultas Teknobiologi, Universitas Atma Jaya Yogyakarta. (2014)

23. Ni `mah, L. Manurung, F.B., Pramita, E., Lightweight Concrete Production by Gypsum from Waste Materials of Clamshell and Eggshell, J Journal of Applied Environmental and Biological Sciences www.textroad.com, ISSN: 2090-4274, 8(1)125-133. (2018)

24. Nimah, L., Sutomo, E.W., Simbolon, R.J., Manufacture Of Gypsum Board From Eggshell Waste Material, ARPN Journal of Engineering and Applied Sciences, www.arpnjournals.com ISSN 1819-6608, VOL. 11, NO. 16, pp. 9933-9940. (2016) 